\title{
BIOLOGY, INCIDENCE AND GENERAL CONTROL. OF THE LUCERNE STEM NEMATODE
}

\author{
F. H. Wood \\ Plant Diseases Division, DSIR, Auckland
}

Summary

The symptoms, life-history and disease cycle of the stem nematode (Ditylenchus dipsaci Kuhn) in lucerne are discussed. Those features that contribute to an understanding of the problems involved in controlling stem nematode infestations are emphasized. Evidence is presented which indicates that $D$. dipsaci is widely distributed in the South Island of New Zealand. General control measures are considered with emphasis on the importance of management practices in dissemination of the pathogen.

\section{INTRODUCTION}

INFESTATION of lucerne stands by the stem nematode (Ditylenchus dipsaci Kuhn) is one of the major problems facing growers throughout the world. The nematode was first recorded from lucerne in New Zealand by Morrison (1957). Since then, it has been suggested that nematode damage to lucerne stands may be responsible for low seed production in some areas (Iverson and White, 1959) and premature "running-out" of some stands (Palmer, 1967).

Knowledge of the biology of $D$. dipsaci is fundamental to an understanding of the role of the nematode in plant disease, its survival and spread, and to the application of control measures. To develop such an understanding, the biology and general control of the stem nematode is considered with particular reference to lucerne production in New Zealand.

\section{SYMPTOMS}

Plants infested with D. dipsaci are characteristically stunted and distorted. Affected tissue is swollen and often feels spongy. Injury is located primarily in the crown and affects the young buds and stem bases where infected buds become thickened and may fail to elongate and the basal stem region may become cracked and brown. Severe infestations result in death of plants.

In the field, infestations are generally first observed as patches of stunted plants about 1 metre in diameter. The patches are most evident in spring when normal growth of surrounding plants emphasizes the stunting effect. The infested areas gradually extend in diameter, usually in the direction of natural drainage.

Although $D$. dipsaci is an endoparasitic species, nematodes are not necessarily present in all parts of an infested plant. Their location is irregular, with most occurring at the apical growing points or at the base. Side shoots are not always infested throughout their length and sideshoot infestations appear to be independent of the position of infestation 
on the main stem (Palo, 1962). As the growing season progresses, normal growth of side shoots may mask the effect of infestation on the foliage production of the whole plant.

Ditylenchus dipsaci is carried up passively as the plant grows. Infestation of apparently normal shoots can be evidenced by distortion of lateral buds and leaf petioles at any point along the stem. Passive upward movement in this manner may result in infestation of the flowering head. Palo (1962) reported finding $D$. dipsaci in petals, sepals and developing ovaries of flowers, and in green seed pods.

\section{LIFE HISTORY}

The life cycle of $D$. dipsaci involves an egg, four juvenile stages, and an adult stage. The first-stage juvenile develops within the egg and the young nematode emerges in the second stage form. Juveniles undergo three further moults before the adult stage is reached. All stages of this cycle are found within diseased lucerne tissue.

Although little work has been carried out on the duration of the developmental stages of $D$. dipsaci on lucerne, Yuksel (1960) reported a comprehensive study of the life-cycle of the onion race of the nematode. Eggs hatched about 7 days after they were laid: the first juvenile stage (within the egg) lasted 5 to $51 / 2$ days; the second juvenile stage (first post-hatch stage) lasted 2 to $2 \frac{1}{2}$ days; the third stage 3 to $31 / 2$ days; and the fourth (pre-adult stage) 4 to 5 days. Young females begin laying eggs about 4 days after the final moult. Mating is necessary for reproduction and a single male is able to fertilize more than one female. The egg laying capacity of individual females ranged from 207 to 498 eggs. Longevity of both males and females was 45 to 73 days.

The minimum generation time of the Canterbury race of the lucerne stem nematode was found to be 25 days at 15 to $20^{\circ} \mathrm{C}$ on three-week-old seedlings (unpubl. data). However, the duration of the cycle may be modified by the ability of the fourth stage (pre-adult) juvenile to survive in an anabiotic or quiescent form. Desiccated fourth-stage juveniles may persist in an inactive state in plant material for several years, and, on rewetting, resume activity. Fielding (1951) reported survival of D. dipsaci in dried teazle even after 23 years. Palo (1962), on the other hand, found that lucerne hay kept under normal dry conditions was nearly devoid of living nematodes after one year; survival was increased under dry conditions and reduced under high humidity. Similarly, nematodes that leave the host tissue and migrate into soil are unable to become quiescent while they are in a moist environment. Miyagawa and Lear (1970) showed that active fourth-stage juveniles survived and remained infective for 212 days at $15^{\circ} \mathrm{C}$ in the absence of host plants.

\section{DISEASE CYCLE}

Invasion of above-ground plant tissue occurs by way of the stomata, or by direct penetration through the terminal and apical buds, the cotyledons and embryonic leaves (Krusberg, 1961). Juveniles and adults are capable of infecting plants but, because of its survival ability, the fourth juvenile stage is probably responsible for establishing most new infestations.

Reproduction is rapid within the host tissue. Inoculum loads as low as 5 adult and pre-adult nematodes of the Canterbury lucerne race gave rise to 185 to 605 individuals per lucerne seedling after six weeks at 15 to $20^{\circ} \mathrm{C}$ (unpubl. data). 
Migratory activity is greatest when plants and soil are wet; during periods of rain, dew, or irrigation. Passive dissemination in water is indicated by the more rapid extension of nematode patches in the direction of natural drainage, particularly if the area is irrigated. All stages may be carried in this manner, although Thorne (1961) found that, of 11,910 $D$. dipsaci recovered from 100 gal of waste water from an infested field, most were pre-adults.

Any means by which plant material is spread, whether in a dried or fresh state, provides a mechanism for dissemination of the nematode. Brown (1953) suggested that infestations may originate from nematodes associated with seed. Subsequent reports have confirmed that $D$. dipsaci may be present in dressed seed samples (e.g., Thorne, 1961; Guinez, 1969). However, the evidence indicates that the nematodes are present as contaminants, that is, they occur on the surface of seed or in dried fragments of seed capsules, flower parts, stems or leaves, rather than in the seed (Brown, 1957; Palo, 1962; Wood, unpubl. data).

The species $D$. dipsaci includes a number of biological races that are identified on the basis of specific host reaction. The host range of the lucerne race may include a number of weeds. Barker and Sasser (1959) found several weed species infected with $D$. dipsaci in infested lucerne fields in North Carloina: buttercup (Ranunculus abortivus) ; field speedwell (Veronica arvensis); neckweed (Veronica perigrina); red dead-nettle (Lamium purpureum); white-top (Erigeron annuus); chickweed (Stellaria media); dandelion (Taraxacum officinale); and wild onion (Allium vineale). Reproduction was apparent in all but field speedwell and dandelion. Hence alternate hosts may facilitate carry-over between lucerne crops.

\section{DISTRIBUTION AND INCIDENCE}

Diagnostic service records show that lucerne stem nematode is present in Southland, Otago, Canterbury and Marlborough in the South Island and P. S. Dale (pers. comm., 1972) isolated D. dipsaci from a lucerne crop in the Rangitikei region of the North Island. The occurrence of $D$. dipsaci in the South Island was further demonstrated in a survey carried out by Dr I. D. Blair on factors likely to be linked with deterioration of lucerne crops. During October to April of the years 1966 to 1968,160 crops were inspected and widespread trace infestations of stem nematode were found. In $4.4 \%$ of the crops, the incidence was assessed at 1 to $5 \%$ infested plants. The prevalence of the pathogen in Canterbury has been more recently emphasized in a survey of field-dressed lucerne seed samples from 92 seed crops. Initial assessment, based on Baermann funnel extractions from $100 \mathrm{~g}$ samples from each seed line, revealed an incidence of $10.8 \%$, with infestations ranging from 1 to 18 nematodes per sample. Subsequent analyses of four $100 \mathrm{~g}$ replicates of 37 of the seed lines resulted in an infestation of approximately $30 \%$. Thus the patchiness of nematode infestations in the field is reflected in aggregation of nematodes in fielddressed seed samples and it follows that the incidence of $D$. dipsaci may in fact exceed the $30 \%$ indicated by the extractions.

\section{GENERAL CONTROL}

\section{CROP Rotation}

Crop rotation is designed to reduce nematode populations to a level at which crop damage is minimized. However, unless $D$. dipsaci is eliminated, 
the perenniality of lucerne stands ensures adequate opportunity for subsequent increase and spread. In the long term, the present of low initial inoculum levels may assume major importance. Crop rotation would be more successful on light than heavy soils but in either situation the presence of weed hosts may facilitate carry-over of sufficient inoculum to initiate new infestations.

\section{Chemical Control}

Because of the endoparasitic habit of $D$. dipsaci, systemic nematicides are necessary for control. The lack of effective materials that may be applied to the foliage and translocated downwards, or applied to the soil and taken up by the roots, has frustrated attempts to control infestations by the application of chemicals. Organophosphorus compcunds have been successful in some instances (e.g., Bergeson, 1955; Barker and Sasser, 1959), but trials in New Zealand (Brewerton et al., 1969) have not given satisfactory results.

Chemicals have been used to eliminate stem nematodes associated with lucerne seed. Page et al. (1959), and Hague and Clark (1959) fumigated lucerne seed with methyl bromide, but the concentration-time-product must be controlled within fairly narrow limits to ensure that the nematodes are killed without seriously affecting the germination of seed (Page et al., 1959; Gostick, 1963; Gostick and Cranston, 1964).

\section{HYGIENE}

As viable inoculum is readily transported in plant debris, care must be taken to ensure that infested plant material is not transported between lucerne stands. Plant debris carried on harvesting machinery or infested lucerne hay, are two potential sources of inoculum.

\section{DISCUSSION}

Attempts to control $D$. dipsaci infestations in lucerne are complicated by the endoparasitic habit of the nematode, the absence of efficient nematicides, and the presence of a persistent stage in its life-cycle. As suitable chemicals for treating field infestations are unavailable, attention must be directed in the interim toward prevention of spread rather than cure. The problem is compounded by the extensive nature of the lucerne crop. Even if chemicals become available, they must be priced to meet the economic requirements of lucerne production. Spot treatment of patches may become a viable proposition in the future, particularly in spring when the patches are most readily identified and before management and harvesting practices disperse the inoculum. However, at best, this approach could only minimize spread rather than eliminate infestations.

Many lucerne growers currently follow a practice of feeding lucerne hay to stock on lucerne stands during winter. Crops benefit from enhanced nutrient return and from some weed control. Although the level of viable inoculum may decrease with storage of lucerne hay, stem nematode infested material is a most efficient vehicle for dissemination of the pathogen. With the incidence of $D$. dipsaci already so high in crops, it is apparent that continuation of this practice can only result in escalation of the problem.

Although treatment of lucerne seed with methyl bromide eliminates associated nematodes, examination of infested Canterbury lucerne seed 
lines, both field-dressed and machine-dressed samples, has shown that nematodes are removed by careful seed cleaning (unpubl. data). The pathogen is harboured in plant debris in field-dressed samples, and therefore, provided the efficiency of the cleaning procedure is maintained, the cost of fumigating seed with methyl bromide does not appear to be justified. On the other hand, it is apparent that sowing field-dressed seed or "seconds" is a false economy.

The existence of biological races of $D$. dipsaci is well recognized, but the existence of biological variation between populations within a race may be overlooked. Variation within races may be expressed as slightly different host ranges and in variable virulence to different varieties of lucerne. The possibility of biological variation between populations of stem eelworm in New Zealand has not been considered. Clearly, such studies are essential to considerations of control, particularly where longterm projects such as breeding for resistance are involved.

\section{ACKNOWLEDGMENTS}

Thanks are due to Dr I. D. Blair, Head of the Department of Microbiology, Lincoln College, for making his survey data available for consultation; and to I. C. Harvey, Officer in Charge, Plant Diagnostic Laboratory, Department of Agriculture, Lincoln, for records of stem eelworm.

\section{REFERENCES}

Barker, K. R.; Sasser, J. N. 1959. Biology and control of the stem nematode Ditylenchus dipsaci. Phytopathology, 49: 664-70.

Bergeson, G. B., 1955. The use of systemic phosphates for control of Ditylenchus dipsaci on alfalfa and daffodils. Pl. Dis. Reptr, 39: 705-9.

Brewerton, H. V.; McGrath, H. J. W.; Grandison, G. S., 1969. Thionazin residues on lucerne and red clover. (Experiments for control of Ditylenchus dipsaci). N.Z. Jl agric. Res., 12: 171-6.

Brown, E. B., 1953. Stem eelworm in lucerne. Pl. Path., 2: 54. 369-75.

Fielding, M. J., 1951. Observations on the length of dormancy in certain plant infecting nematodes. Proc. helminth. Soc. Wash., 18: 110-2.

Gostick, K. G., 1963. Effect of temperature on methyl bromide fumigation of lucerne seed for control of stem eelworm. Pl. Path., 12: 62-4.

Gostick, K. G.; Cranston, D. M., 1964. The sorption of methyl bromide by lucerne seed. Pl. Path., 13: 1-6.

Guinez, Abdon S., 1969. Transmission de nematodes fitopatogenos por semillas de forrajeras. Agricultura tec., 29: 139-41. [Helminth. Abstr. Ser. B. 1970, 40 (3): 65 (Abstr.).]

Hague, N. G. M.; Clark, W. C., 1959. Fumigation with methyl bromide and chloropicrin to control seed-borne infestations of stem eelworm (Ditylenchus dipsaci) on lucerne (Medicago sativa). Meded. LandbHogesch. Gent., 24: 628-36.

Iverson, C. E.; White, J. G., 1959. Improvement of Medicago glutinosa. A. Rev. Canterbury agric. Coll. N.Z.: 95-8.

Krusberg, L. R., 1961. Studies on the culturing and parasitism of plant parasitic nematodes, in particular Ditylenchus dipsaci and Aphelenchoides ritzemabosi on alfalfa tissues. Nematologica, 6: 181-200. 
Morrison, L., 1957. New records of eelworm infestations of liceme and Agropyron scabrum. A. Rev. Canterbury agric. Coll. N.Z.: 62-3.

Miyagawa, S. T.; Lear, B., 1970. Factors influencing survival of Ditylenchus dipsaci (Kuhn, 1857) in soil. J. Nematol., 2: 139-42.

Page, A. B. P.; Hague, N. G. M.; Jakabsons, V.; Goldsmith, R. E., 1959. Fumigation of lucerne seed with methyl bromide for the control of the stem eelworm Ditylenchus (Anguillulina) dipsaci. J. Sci. Fd Agric., 10: 461-7.

Palmer, T. P., 1967. Lucerne breeding in New Zealand. In: Langer, R. H. M. (ed.): The Lucerne Crop: 85-95. Reed, Wellington.

Palo, A. V., 1962. Translocation and development of stem eelworm, Ditylenchus dipsaci (Kuhn) in lucerne, Medicago sativa L. Nematologica, 7: 122-32.

Thorne, G., 1961. Principles of Nematology. McGraw-Hill, N.Y. 553 pp.

Yuksel, H. S., 1960. Observations on the life cycle of Ditylenchus dipsaci on onion seedlings. Nematologica, 5: 289-6. 



\title{
FUNGOUS DISEASES OF CEREALS
}

\section{CHAIRMAN'S SUMMARY}

\author{
H. C. SMITH \\ Crop Research Division, DSIR, Lincoln
}

\begin{abstract}
Disease Survey: Dr F. R. Sanderson's key to wheat diseases provides a valuable reference to enable more accurate effort to survey disease loss in this crop. This should be done for the other main crops, especially barley and oats, but also peas, lucerne, brassicas, potatoes and pasture plants. With the large number of plant pathologists now active in N.Z., it is regrettable that more effort is not made to establish the losses caused by diseases.

B. I. Arnst described the methods used to assess the incidence of mildew in cereal crops and stressed the need for standardization of methods. He did not mention the valuable technique of aerial survey which is under rapid development but equally well needs accurate verification and standardization. I trust there will be a greater co-ordinated and continuing effort in future to measure disease losses and match research to their importance.

EPIDEMIOLOGY: Basic studies on the environmental effect on cereal diseases have been lacking but Dr I. D. Blair's survey indicates the need for basic information on how the pathogenic race situation of rusts and mildew changes over the years-how this is affected by the weather and changes in varieties and farm practices. W. H. Risk, Dr Blair, C. D. Forgie and $\mathrm{Mr}$ Arnst seem very impressed with the ability of chemists to develop new materials to control varicus diseases, but a note of caution should be sounded. A basic knowledge of the epidemiology is even more essential to obtain the best and economical result from these chemicals which will still need to be applied with full knowledge of the plant's reaction to both pathogen and chemical and of course the best time of application.

Plant BREEDING: Dr J. M. McEwan described the failure of major gene resistance breeding to rusts and mildew but pointed out that plant breeders were now recognizing there are other more effective and more permanent sources of resistance available and being utilized in the plant breeding programme. New varieties of crops bred in N.Z. do have this more permanent type of resistance which, although it does not confer immunity, does give quite an adequate degree of resistance in the field. Plant breeding is certainly long-term research but it will win out in the end because of the zero cost to the grower and its long-term effectiveness.

DiseAse ERADication: For many years it has been the aim of the Canterbury Malting Co to eradicate loose smut in barley crops. The company first did co-operative research with DSIR in the early 1930s and actively led co-operative work aimed at eradication by hot water treatment of seed. This work was eminently successful, as shown by the very low incidence of loose smut since that date and by comparison with the occasional crop of feed barley grown from farmer-saved seed or importation from Europe.

The economic value of this work must be measured in the thousands of acres of healthy crops grown in successive generations from treated seed. This tends to be overlooked in trials comparing the cost of seed treatment directly with the reduction in disease in the first subsequent crop.

The papers on smut control showed the excellent results achieved by new chemicals which have now completely replaced hot water treatment in pure seed production and certification schemes.
\end{abstract}

